\title{
The Effect of Environmental Accounting Implementation, Research and Development to Earnings Quality and Ethics as to Moderating Variables
}

\author{
Verliani Dasmaran $^{1}$, Susi Dwi Mulyani ${ }^{2}$ \\ 1. Accounting Doctoral Student, Trisakti University Indonesia \\ 2. Accounting doctoral Lecturer, Triskti university Indonesia
}

\begin{abstract}
The purpose of this Papers is to test the Implementation of Environmental Accounting (EA), Research Development (RD) on Earning Response (ERC) and ethics to be moderating variables, this study also uses four control variables namely earnings persistence, company growth, size, the capital structure of the company. The research method uses secondary data with multiple regression testing with the analysis unit 124 annual reports of manufacturing companies in all sectors listed on idx.co.id data processing using eviews 9. The results of the research prove that environmental accounting is disclosed by the company is not able to influence the earnings coefficient response (ERC) company, research and development disclosure (RD) annual report can significantly influence the Earning response coefficient with a significant level of $10 \%$, and the application of ethics in the implementation of Environmental Accounting can strengthen or moderate the Environmental Accounting for Earning Response Coefficient, while the ethics applied in Research and Development cannot moderate the Earning Response Coefficient. Of the four control variables that were regressed, only 1 variable affected namely company size, while all four variables had no significant effect on ERC. This research can contribute to the science of the importance of disclosure and academics, policymakers, and stakeholders
\end{abstract}

Keywords : Environmental Accounting, Riset And Development,Ethics,Earning Response Coefficient

DOI: $10.7176 /$ RJFA/10-24-17

Publication date: December $31^{\text {st }} 2019$

\section{Introduction}

Throughout 2017, the Jakarta Regional Police handled 133 environmental cases and 17 cases including Citarum river pollution. The culprits are companies along the river, they dump liquid waste into the river. The number of cases has increased compared to 2016, where only 88 of these cases prove that many companies do not apply environmental accounting in the company's operations. This will have a broad impact on corporate sustainability.

The company is not only as an economic unit but also as a social institution so that it is hoped that the company can progress and develop harmoniously with the community around the company having a symbiotic relationship of mutualism. The company's existence is not limited to the environment because the company is in a certain environment. Many companies are required to pay more attention to the existing environmental problems so that the survival of the company is maintained, companies must build relationships with the environment by protecting the environment. One of the company's responsibilities in dealing with corporate environmental problems is a comprehensive approach to the company's operation, products, and other facilities.

The form of corporate responsibility to the environment is part of CSR (Corporate Social Responsibility) where CSR includes economic activities, social activities and the last is environmental activities (Yoon 2015). CSR or Corporate Social Responsibility is a form of obligation base on corporate awareness as an effort to improve its relationship with the community and the environment. Forms of corporate responsibility to the environment can incur costs that are often known as environmental costs, cover detection costs, prevention costs, internal-external failure costs. All costs issued by the company are called corporate social responsibility funds and recording the use of CSR funds using environmental accounting

Environmental accounting in the company can be accessed by stakeholders by means of disclosure of quantitative or qualitative data. a firm can utilize disclosure as a strategic tool, trying to influence perceptions of stakeholders (Chen, Chen, and Patten 2015). Disclosure is expected to provide a signal for stakeholders, especially potential investors, regarding he expectation of the firm in the future and show the added value of the company for its concern for the economic, social and environmental impacts arising from the firm activities.

A company to be able to compete in the market and exist in maintaining and developing its business in addition to being able to provide confidence in consumers also needs innovation to keep consumers loyal. Innovation results from effective research and development so that you can compete and become a market leader. 
The Nokia phone company from Finland could go bankrupt in 2013 after 14 years of dominating the global market, Kodak photography company also went bankrupt, and in 2011 the Blackberry Research company in Motion (RIM). This Canadian smartphone suffers from a similar fate, almost all due to unsuccessful innovation being unable to compete in product development. This clearly explains the importance of research and development in the company so that innovation will continue

$\mathrm{R} \& \mathrm{D}$ as an Inherent business activity, two basic and important concepts. First, the basic concept that R\&D is an important element in innovation, and innovation is very important for the prosperity of a business. but which in practice treats it as a "frill" or as an "overhead" which, in vain. This does not mean that every company needs to need to start an original large-scale, independent research program. The second concept inherent in the rule of thumb is the concept that $R \& D$ is a management activity, to be produced with the desired results. R\&D is a business activity. Like all business activities, it can be well managed and directed, or poorly managed and directed. Like all business activities, it carries an element of failure risk, risks which can be somehow offset by providing options and alternatives. With all innovations, there is, of course, an unknown element that sometimes produces unexpected winners unexpected failures.

In the implementation of Environmental Accounting and Research and Development that is carried out by companies, it is necessary to have good rules and good governance to foster internal and external relations, it is necessary to conduct ethics as a control and control tool that can strengthen implementation. Earnings Response Coefficient is an indicator of how the earnings quality of companies tends to be influenced by factors sourced from financial statements, so in this study, the five control variables are earnings persistence, company growth, company size, capital structure, and stock beta. From the description above it can be related to how companies implement Environmental Accounting so that the members are a good signal for investors and other external parties so that expectations for the company are better so that the value of the Coefficient Earning Response (Schimke and Brenner 2011) of the company will increase, so the Research and Development Intensity becomes a right the company's innovation process is more advanced and member hopes are more positive for the company and it can be driven by ethics from the company, so in this papers, we are interested in taking the title of research "Implementation of Environmental Accounting, Research and Development Intensity Against Earning Responsible Coefficient and Ethics into variables moderating "

\section{Literature Review and Hypothesis}

\subsection{Stakeholder Theory}

Stakeholders are a group of people or individuals who influence each other and are influenced by the achievement of certain goals of the organization (Freeman and Mcvea (2001). Stakeholders are parties who influence the company in traditional decision making. The stakeholder approach to strategic management has several related characteristics that serve as features of the difference. Stakeholder theory suggests how stakeholder management has influenced management practices.

The stakeholder category is an effort to group people or parties who play a role in the existence of the company. The first category is called the primary stakeholders. The primary or primary stakeholders are people or parties who have direct interests in the programs, policies, and decisions taken. And stakeholders are the main determinant or main decision-maker. The second secondary stakeholder is the party directly involved with the policy while the stakeholder has a key stakeholder is the third stakeholder, namely the association of people legally, with authority in determining the policy.

\subsection{Environmental Accounting}

Environmental accounting can be defined as an area of accounting that functions and identifies, measures, evaluates and reports environmental cost accounting. In the opinion (Qian 2012) that Indirectly, accountants and environmental accounting can play a role in helping environmental management problems. Meanwhile, according to (iksan 2008) environmental accounting is the prevention, reduction or avoidance of environmental impacts, starting from the re-improvement of events that cause disaster for these activities. Whereas (R.H.GRAY 1994) stated the role of accountants in helping management overcome environmental problems through 5 (five) stages, namely:

1. The current accounting system can be modified to identify environmental problems on expenditure issues such as packaging costs, legal costs, sanitation costs, and other costs relating to environmental effects.

2. Negatives of the current accounting system need to be identified, such as investment appraisal issues that do not take environmental issues into account.

3. The accounting system needs to look far ahead and be more sensitive to the emergence of environmental issues that are always developing. 
4. Financial reporting for external parties in the process of changing, such as changing the size of company work in the community.

5. The new accounting of information systems requires development such as thinking about the possibility of an "eco-balance sheet".

\subsection{Research And Development ( R\&D)}

$\mathrm{R} \& \mathrm{D}$ or Research Development in a company is a research that is widely developed and is a research that can develop products or improve existing products, which is meant by-products not always in the form of hardware but also software or it can also be intangible. Research Development is a method that is used to result in certain products and tested their effectiveness and efficiency with that method (Sugiyono 2009). Borg and gall (1985) Research Development is a tool for the result of innovation and is a force in maintaining the market. Besides research and development, it is a method used to develop and upgrade products used in education and learning. from these explanations seen things that must be considered in research and development, that is finding, developing and validating the product (Validate)

\subsection{Earning Response Coefficient (ERC)}

Scott (2015) states that the concept that shows the correlation between earnings the company and stock returns is the earnings response coefficient. Suwardjono (2010) explains that the earning response coefficient is how far the sensitivity of stock returns to unexpected earnings, which presents information that has not been captured by the market so that the market will react at the time of earnings announcements. Investor's reaction to earnings information presented in the financial statements varies. ERC is the effect of each unexpected earnings on share returns, which is shown as the slope coefficient in the regression of abnormal returns of stocks and earning unexpectation (Cho and Jung 1991); (Barth, Beaver, and Landsman 2001) that ERC is also called the coefficient of the sensitivity of accounting earnings, which determine of the sensitivity of changes in share prices to changeover in accounting earnings. Market reaction is seen by changes in the market price of the firm or stock returns. so that ERC is determined by the company's growth rate. (Collins and Kothari 1989)

\subsection{Ethics}

James J. Spillane SJ argues about the definition of Ethics, which is to consider or pay attention to human action in a decision related to morals. Ethics is more aimed at the use of human intellect with objectivity to determine the truth as well as one's behavior to others. work ethic is a reference used by a person or company as a guideline in carrying out the work of his business activities so that the activities they do do not harm other individuals or institutions

\subsection{Development of Hypotheses}

Environmental Accounting can be described in Environmental Disclosure which can give a signal to stakeholders in making decisions, the signal can be good or vice versa, so it is expected to respond to the market better, this market response makes the value of ERC so large and vice versa (Widiastuti 2004) (Hopwood 2009) which shows that the strength of investor response to earnings information signals (ERC) is a function of future uncertainty. Barth, Beaver, and Landsman (2001) The greater the noise in the firm reporting system (the lower the quality of earnings) or the smaller the ERC. and the more complete the disclosure related to environmental accounting, the better the ERC, the authors describe it in the hypothesis

\section{H1: There Is a Positive Influence On The Implementation Of Environmental Accounting To Earnings Response Coefficient}

Research and Development is the firms strategy in facing the competitive world of business, in the R\&D industry is the spearhead of producing new products needed by the market. This R\&D will create innovation. Without innovation, no one company can survive (Daft, 2011), the results of Research and Development can be reflected in how companies try to explore so that the possibility of higher profits will be generated, this is a consideration of investors and external parties in reading the business direction and predict the company's progress. (C. Padgett and Ignacio Galán Zazo 2010) Thus it will be seen that stock prices move up or down, the Earnings Response Coefficient will also increase, so the better the Research and Development information on ERC will be better also illustrated with a hypothesis

\section{H2: There Is a Positive Influence On Research And Development Intensity On Earnings Response Efficient}

Ethics or code of conduct in doing business in a company makes the implementation of Environmental Accounting more successful, where ethics will require employees and leaders to behave ethically in business, if ethical principles are rooted in the company making it a culture, violation of ethical rules is a violation of the law that has the consequences. The company's ethical values are by the principles of GCG,namely Accountability,Transparency, Responsibility, Indepandency dan Fairness and cooperation. Corporate ethics is 
revealed to strengthen stakeholder confidence in company performance and will increase market responses including ERC to be higher, ethics can be created from business ethics and ethics and make it work for companies (Yurchenko et al. Nd) who want to remain relevant before stakeholders and society

Similarly, in environmental accounting, it would be more effective to be run by a company if the ethics in the company have been implemented. In this study the authors describe ethics as can moderate the relationship between environmental accounting and ERC, into the following hypothesis:

\section{H3: Ethics Can Moderate Of Influence Environmental Accounting to Earnings Response Coefficien}

Ethics are needed in the business world so that good relations and fairness are maintained. Business ethics not only regulates the company's internal relations, but has now expanded to a broader scope, such as the Global Compact, Decent Work, and Company Social Responsibility. On the other hand, unethical actions taken by companies will provoke retaliation from competitors, consumers and the public that are in contradiction with the company. This, of course, can affect the decline in company value and sales. Likewise, applying good ethics in carrying out Research and Development will strengthen the value of the company including the Earning Response Coefficient

\section{H4: Ethics can moderate the Effect of Research And Development on the Earnings Response Coefficient}

\section{Research Methodology}

This study is quantitative research, which analyzes the data in the form of numerical (numbers) which are managed by the statistical method, (Arikunto 2007) using the Verification Method, which is a method of testing the goals that have been set whether it is by or not with existing theories to make new theories and create new knowledge. The research hypothesis including the Associative hypothesis is the allegation of the relationship between two or more variables, with cross-section data consisting of 124 manufacturing companies in all sectors, in 2017 with annual report data and sustainability reports from the Indonesian exchange (www.idx.co.id)

\subsection{Measurement of Variables}

Table 3.1 Measurment of Variabel

\begin{tabular}{|c|c|}
\hline Variabel & Measurment \\
\hline $\begin{array}{l}\text { Environmental } \\
\text { Accounting }\end{array}$ & $\begin{array}{l}\text { Environmental Accounting measurements taken from GRI standards that have been applied July } 1 \text {, } \\
2018 \text { consists of } 8 \text { indicators relating to the environment, namely the number of provisions disclosed } \\
\text { GRI provisions amounted to } 30 \text { items so the formula uses: } \\
\text { EADi }=\frac{m i j}{x i j} \\
\text { EADi = Environmental Accounting Disclosure Index } \\
\text { nij = number of items disclosed by the Company disclosing, each item revealed is given a score of } 1 \\
\quad \text { and if not } 0 \\
\text { xij = number of GRI conditions }(30 \text { items }\end{array}$ \\
\hline $\begin{array}{l}\text { Research and } \\
\text { Development }\end{array}$ & Research and Development measurement with the dummy variable used 1 and 0 score \\
\hline Ethics & $\begin{array}{l}\text { Ethical measurements used the Code of Conduct Disclosure Ratio } \\
\mathrm{Ei}=\frac{E d}{n t} \\
\mathrm{Ed}=\text { number of code of conduct disclosures by the company } \\
\mathrm{Dt}=\text { the highest number of code of conduct disclosures by the company as the object of research }\end{array}$ \\
\hline $\begin{array}{l}\text { Earning } \\
\text { Response } \\
\text { Coefficient }\end{array}$ & $\begin{array}{l}\text { Utaminingtyas and Ahalik (2010) ERC is the response coefficient of accounting profit obtained by } \\
\text { regressing cumulative abnormal return (CAR) with unexpected return (EU). ERC calculations are } \\
\text { consistent with research Abolfazl (2013). } \\
\text { CARit }=\alpha 0+\alpha 1 \text { UE it }+\varepsilon\end{array}$ \\
\hline $\begin{array}{l}\text { Earnings } \\
\text { Persistence }\end{array}$ & $\begin{array}{l}\text { Earnings persistence is the correction of expected accounting earnings (future earnings) as seen from } \\
\text { current year earnings (Current Earning) which are influenced by changes in stock prices, earnings } \\
\text { perceptions are shown by how much the revision (Penman and Zhang 2002). Scott (2009) a revision of }\end{array}$ \\
\hline
\end{tabular}




\begin{tabular}{|c|c|}
\hline & $\begin{array}{l}\text { expected future earnings that is implied by current year's earnings innovation so that earnings } \\
\text { persistence is shown from the current year's earnings that are associated with a shift in stock price. The } \\
\text { magnitude of this revision shows the level of earnings persistence. The persistence of accounting } \\
\text { income is measured using a regression coefficient between current period accounting earnings and past } \\
\text { period accounting earnings. Data scale used is ratio, with the formula: Eit }=\beta 0+\beta 1 \text { Eit- } 1+\varepsilon \text { it }\end{array}$ \\
\hline Capital Structure & $\begin{array}{l}\text { According to Keown et al (2008) capital structure is a guide or a combination of long-term funding } \\
\text { sources used by companies. The capital structure shows a comparison both in absolute and relative } \\
\text { terms between debt and own capital ( ratio debt to totas assets) }\end{array}$ \\
\hline Size & Size measurement with total assets or LN total assets \\
\hline $\begin{array}{l}\text { Company } \\
\text { Growth }\end{array}$ & $\begin{array}{l}\text { The company's growth use the formula } \\
\mathrm{CG}=\frac{\text { total Asset } t-\text { total aset } t-1}{\text { tomal axet } t-1}\end{array}$ \\
\hline
\end{tabular}

\section{Discussion}

Table 4.1 Statistic Description

\begin{tabular}{|l|c|c|c|c|c|c|c|c|}
\hline & & & & & LOG & LOG & & SIZE \\
\hline Mean & -2.716918 & -0.324700 & 0.653226 & -0.281082 & -1.343782 & -0.885345 & -0.244674 & -0.941475 \\
\hline Median & -2.723600 & -0.244402 & 1.000000 & -0.287682 & -1.268034 & -0.977261 & -0.287700 & -0.830124 \\
\hline Maximum & -2.369500 & 0.154179 & 1.000000 & 0.117783 & 2.074359 & 2.106058 & 0.999000 & 1.870417 \\
\hline Minimum & -2.784000 & -1.098712 & 0.000000 & -0.980829 & -3.900737 & -2.711464 & -0.980800 & -4.828314 \\
\hline Standard devias & 0.049348 & 0.272115 & 0.477874 & 0.196676 & 0.758992 & 0.801120 & 0.288999 & 0.857077 \\
\hline Skewness & 5.465217 & -1.002381 & -0.643883 & -0.477976 & 0.048629 & 0.888018 & 1.565789 & -0.525884 \\
\hline Kurtosis & 35.92159 & 2.934861 & 1.414585 & 3.540392 & 6.299612 & 5.400280 & 7.812667 & 7.012690 \\
\hline Jarque-Bera & 6217.077 & 20.78711 & 21.55472 & 6.230308 & 56.30065 & 46.06419 & 170.3375 & 88.90745 \\
\hline Probability & 0.000000 & 0.000031 & 0.000021 & 0.044372 & 0.000000 & 0.000000 & 0.000000 & 0.000000 \\
\hline & & & & & & & & \\
\hline Sum & -336.8978 & -40.26283 & 81.00000 & -34.85418 & -166.6289 & -109.7828 & -30.33960 & -116.7429 \\
\hline Sum Sq. Dev. & 0.299535 & 9.107732 & 28.08871 & 4.757823 & 70.85644 & 78.94055 & 10.27303 & 90.35353 \\
\hline & & & & & & & & \\
\hline Observations & 124 & 124 & 124 & 124 & 124 & 124 & 124 & 124 \\
\hline VIP & 2,932 & 2,379 & 3,923 & 3,935 & 1,050 & 5,837 & 1,036 & 5,764 \\
\hline $\begin{array}{l}\text { Prob } \\
\text { Chisquare }\end{array}$ & 0,109 & & & & & & & \\
\hline
\end{tabular}

In the table, above it can be explained that the amount of data (observation) is 124 companies that study with cross-section data from the company's annual report in 2017, can be seen the mean, maximum, minimum, and standard deviation, Skewness is indicator measure of asymmetry distribution of data the mean. Skewness of normal distribution is 0 (Winarno 2015), there is no skewness data that has a value of 0 and 6 variables have a positive skewness namely ERC, Ethics, earnings persistence, growth, size while 3 negative skewness variables namely Environmental Accounting, Research Development, and DER, Kurtosis is measuring height or distribution, kurtosis of a normally distributed data is 3 .

ERC variable, Persistent earnings, growth, size, DER is leptokurtosis to normal while the Environmental Accounting and ethics variables approach the normal distribution of 2.93 and 2.89 while the Research and development data has a flat or flat-gourd distribution. Jarque-Bera is a statistical test to know the data are normally distributed, also used to measure differences in skewness and kurtosis of data and compared to normal data. Robustibility shows the possibility of fallowJarque values exceeding (absolute values) observed values under the null hypothesis. Probability value small is lead to the rejected of the null hypothesis, all variables have a probability value of 0 smaller than $\alpha=5 \%$, VIP values indicate data are free from multicollinearity and free from heteroskedasticity with a prob chi-square value of 0.17 


\subsection{Regression Test}

Table 4.2 Regression

\begin{tabular}{|l|r|r|r|l|}
\hline Variabel & \multicolumn{1}{|c|}{ B } & \multicolumn{1}{|c|}{ t } & \multicolumn{1}{|c|}{ Sig. } & \\
\hline (Constant) &,- 187 & $-4,507$ &, 000 & \\
UE &,- 020 &,- 630 &, 530 & Negative Not Significant \\
EA &,- 011 &,- 521 &, 604 & Negative, Not Significant \\
RD &,- 001 &,- 124 &, 901 & Negative, Not Significant \\
Ethics & $-5,742$ &,- 002 &, 998 & Negative, Not Significant \\
Growth & $-4,596$ &,- 150 &, 881 & Negative, Not Significant \\
Persistance &, 001 & 1,586 &, 116 & Positive, Not Significant \\
DER &,- 002 &,- 235 &, 814 & Negative, Not Significant \\
Lnsize &, 000 &, 080 &, 936 & Positive, Not Significant \\
UE_EA &, 023 &, 759 &, 449 & Positive , Not Significant \\
UE_RD &, 076 & 2,413 &, 018 & Positive,Signifikant \\
UE_Growth &, 000 &, 356 &, 722 & Positive, Not Significant \\
UE_Persistance &,- 007 & $-1,683$ &, 095 & Negative, Not Signifikant \\
UE_DER &, 010 & 2,543 &, 012 & Positive, Significant \\
UE_Lnsize &,- 001 &,- 952 &, 343 & Negative Not Signifikant \\
UE_AE_Ethics &, 026 &, 707 &, 481 & Positive Not Significant \\
UE_RD_Ethics &, 087 & 2,217 &, $\mathbf{0 2 9}$ & Positive, Signifikan \\
\hline R-Square & 0,190 & & & \\
\hline Adj. R-Square & 0,068 & & & \\
\hline & & & & \\
\hline
\end{tabular}

From the table above you can see the regression equation

\section{CAR =-0,187-0.20 UE-0,11EA-0,001RD-5,74 Ethics-4,596 Growth+0,001Persistance -0,02DER+ 0,00Lnsize+ 0,23UE*EA+ 0,76UE*RD+0.00UE*Growth $-0,007 \mathrm{UE} *$ Persistence+ 0.01UE*DER- 0.001 UE*Lnsize+ 0,26UE*AE*Ethic +0,087UE*RD*ETIK}

\subsection{Research Analysis}

Coefficient of determination to see how much the contribution of all independent variables to the dependent variable in this papers can be seen from the R-Square in table 4.2 that is equal to 0.190 or $19 \%$ meaning that the independent variable has a contribution of $19 \%$ to the dependent variable and $81 \%$ is affected by other factors. While the Adjusted R Square is the R Square that has been corrected by the standard error value, in this papers the adjusted $\mathrm{R}$ square value is 0.068 or $6.8 \%$

\subsection{Hypothesis testing}

To test the hypothesis of the variable using the t-test and the probability value if the prob value has a value $>0.05$ then the conclusions of the t-test can be accepted or have a significant effect in this study the value of the t-test can be shown in table 4.2 and if we conclude it can be shown in table 4.3 
Table 4.3 : Conclusion

\begin{tabular}{|c|l|}
\hline \multicolumn{1}{|c|}{ Hypothesis } & Conclusion \\
\hline $\begin{array}{l}\mathrm{H} 1: \text { There is a positive influence on the implementation of environmental } \\
\text { accounting on earnings response coefficient }\end{array}$ & Rejected \\
\hline $\begin{array}{l}\mathrm{H}_{2}: \text { There is a positive influence of Research and Development Intencity on } \\
\text { earnings response Coefficient }\end{array}$ & Received \\
\hline $\begin{array}{l}\mathrm{H}_{3}: \text { Ethics Can Moderate Of Influence Environmental Accounting to } \\
\text { Earnings Response Coefficien }\end{array}$ & Rejected \\
\hline $\begin{array}{l}\mathrm{H}_{4}: \text { Ethics can moderate the Effect of Research And Development on the } \\
\text { Earnings Response Coefficient }\end{array}$ & Received \\
\hline
\end{tabular}

\section{Conclusion, Implication and Recommendation}

\subsection{Conclusion}

The results of testing the hypotheses have been described, we obtain conclusions that can be drawn from research on Environmental Accounting, Research and Development and ethics as a moderating variable on the dependent variable ERC (Earning Respose Coefficient) as follows:

1. Empirical evidence shows the results of a positive and insignificant influence between Environmental Accounting Disclosures and the Revenue Response Coefficient (ERC). The results of this study are in harmony with Istulomah Nurul's (2015) and contradict Yoo Chankim (2017) in his research that CSR disclosure has a negative effect on ERC and Environmental Accounting is part of corporate CSR disclosure

2. The results of research and development testing have a significant effect on ERC according to the study of Sharad, et All (2016) Antje Schimke (2014) which supports R\&D that affect financial factors, proving that the development of innovation is able to mobilize the confidence of external factors.

3. Ethics testing as a moderating variable cannot strengthen the influence of Environmental Accounting on ERC. In line with research in other fields which proves ethics cannot moderate budgetary participation Miyati (2012) proves ethics in companies still need to be supported by policies to increase the belief of all parties and gets Earning quality of corporate

4. Analysis of the results proves that Ethics can moderate the influence of research and development on ERC, Brey et al. (2017) states that ethics increases coordination and cooperation in a project to be more harmonious, this proves that ethics strengthens the creation of innovation through research and design so that corporate objectives are achieved including the quality of revenue.

5. Income Persistence does not have a significant influence on ERC. This contradicts the theory in which earnings persistence is used as a measurement tool in measuring the ups and downs of stock prices, Chaney and Jeter (1991); Harahap (2004)

6. Growth as a control variable does not affect ERC, this explains the increase in assets is not an consideration of investors in assessing the quality of corporate earnings that conflict with research Mulyani et, all (2007)

7. Company size has no influence on ERC in line with (Etty Murwaningsari 2008) which states that size as a control variable has a negative effect on ERC, this proves the quality of earnings is not seen from the size of the company.

8. Debt to Equity Ratio (DER) has a significant influence on ERC that is incompatible with (Rahayu, Suhandak, and M 2019) which states that the return on equity and net profit margins triggers a decrease in of debt in the company's capital structure. manufacturing firm listed on the IDX or the Indonesia Stock Exchang

\subsection{Implications}

Based on these results the theoretical and practical implications can be stated as follows:

1. Choosing an Environmental Accounting measurement method from the point of disclosure in the financial statements with a standard GRI benchmark of 30 items, contributing information that can be considered by investors in analyzing company quality, and adding new standards in the importance of disclosure. 
2. The application of Ethics in the implementation of company activities has a positive impact on company goals, although in this study ethics do not moderate research and development, the measurement of ethics in companies becomes important for investors in analyzing companies.

3. Research and Development become important in product innovation in the company but disclosure in reports related to research and development must be synchronized with financial reporting to provide more complete information to stakeholders.

\subsection{Recommendations for Further Research}

In this study there are some limitations that can be used as recommendations for further research as for the limitations and recommendations in this study:

1. In this study the sample used is limited to manufacturing companies listed on idx.go.id so that generalizations and findings and recommendations cannot be applied thoroughly, then recommendations for future researchers on research can be used in samples of all types of companies so that conclusions can be applied thorough.

2. The use of measurements on the R\&D variable does not fully describe the real conditions of the company while using $R \& D$ expanse is not an easy matter in determining the sample so that it is recommended R\&D research using different measurements

3. ERC (Earning Response Coefficient) research that is used in this study is only 1 year or data cross section so that it does not have a real profit picture then it is recommended for further research more than 1 years

\section{References}

A Chariri dan Imam Ghozali. 2007. "Teori Akuntansi”. Semarang: Badan Penerbit Universitas Diponegoro. Asthana sharad and Yinqi Zhang. 2016. "Effect of R\&D Investments on Persistence of Abnormal Earnings." Review of Accounting and Finance Vol 5 iss: pp 124-139. https://doi.org/10.1108/14757700610668967.

Barth, Mary E, William H Beaver, and Wayne R Landsman. 2001. "The Relevance of the Value Relevance Literature for Financial Accounting Standard Setting : Another View \$." 31: 77-104.

Brenner, Thomas. 2016. "The Role of R \& D Investments in Highly R \& D-Based Firms." (February 2014).

C. Padgett, Robert, and José Ignacio Galán Zazo. 2010. 93 Documentos de trabajo " Nuevas tendencias en dirección de empresas ", No. 13, 2009, pags. 1-23 The Effect of R\&D Intensity on Corporate Social Responsibility.

Chen, Jason, Jennifer C Chen, and Dennis Patten. 2015. "Manipulative Environmental Disclosure: Further Analysis of Corporate Projections of Environmental Capital Spending." (August 2018).

Collins, Daniel W., and S. P. Kothari. 1989. "An Analysis of Intertemporal and Cross-Sectional Determinants of Earnings Response Coefficients." Journal of Accounting and Economics 11(2-3): 143-81.

Erc, Response Coefficient, and Dian Masita Dewi. 2016. "The Role of CSRD on Company 's Financial Performance and Earnings The Role of CSRD on Company' s Financial Performance and Earnings Response Coefficient ( ERC ).” (November 2015).

Freeman, R, and John Mcvea. 2001. SSRN Electronic Journal A Stakeholder Approach to Strategic Management. Hopwood, Anthony G. 2009. "Accounting and the Environment." Accounting, Organizations and Society.

Istiqomah, and Nurul. 2015. "The Effect of Environmental Disclosure o n Earning Response Coefficient ( ERC) ( Case Studies on Basic Chemical Industry Sector and Mining Companies List Ed on Indonesia Stock Exchange in 2012 - 201.” http://etheses.uin-malang.ac.id/2155/3/11520094_Inggris.pdf.

Kasiono, Dedi, and Fachrurrozie. 2016. "Determinan Persistensi Laba Pada Perusahaan Manufaktur Yang Terdaftar Di BEI.” Accounting Analysis Journal 5(1): 1-8.

Kim, Yoo Chan, Inshik Seol, Yun Sik Kang, and Yoo Chan Kim. 2018. "Legal Environment and Stages of Corporate Social Responsibility A Study on the Earnings Response Coe Ffi Cient ( ERC ) of Socially Responsible Fi Rms Legal Environment and Stages of Corporate Social Responsibility."

miyati. 2015. "Pengaruh Partisipasi Anggaran Terhadap Budgetary Slack Dengan Pertimbangan Etika Sebagai The Influence Of Budgetary Participation On Budgetary Slack With." (12): 1-9.

Murwaningsari, Etty. 2008. "Faktor Yang Mempengaruhi Earning Response Coefficient (ERC)." Simposium Nasional Akuntansi XI (1979): 1-27.

Ohlson, James A. 2015. "Market-Based Empirical Research in Accounting: A Review , Interpretation , and Extension.” 20(1982): 249-322.

Padgett, Robert C, and Jose I Galan. 2010. "The Effect of R \& D Intensity on Corporate Social Responsibility." : 407-18.

Penman, Stephen H, and Xiao-jun Zhang. 2002. “The Quality of Earnings , and Stock Returns.” 77(2): $237-64$.

Qian, Wei. 2012. "Environmental Management Accounting and Supply Chain Management." Journal of Cleaner 
Production.

R.H.GRAY. 1994. "Corporate Reporting for Sustainable Development: Accounting for Sustainability in 2000AD." Environmental Values no1: 17-45. http://www.environmentandsociety.org/node/5\%0A505.

Ray Ball, Philip Brown. 1968. "Ball_Brown_JAR_1968.Pdf.” Journal of Accounting Research: 159-78.

Ribeiro, Verónica, Cristina Aibar-Guzmán, Beatriz Aibar-Guzman, and Sónia Maria da Silva Monteiro. 2016.21 Corporate Communications: An International Journal Determinants of Environmental Accounting and Reporting Practices in Portuguese Local Entities.

Rogers, Mary Margaret, Robert A Peterson, and Gerald Albaum. 2013. "Measuring Business Related Ethicality." 6(1): 1-14.

Schimke, A, and T Brenner. 2011. "Temporal Structure of Firm Growth and the Impact of R\&D." Working Paper Series in Economics, Karlsruher Institut für Technologie (KIT) (32). http://www.econstor.eu/handle/10419/48854.

Widiastuti, Harjanti. 2004. "Pengaruh Luas Ungkapan Sukarela Dalam Laporan Tahunan Terhadap Earnings Response Coefficient ( ERC )." 5(2): 187-207.

Yoon, Donghwan. 2015. "Corporate Social Responsibility (CSR) Advertising and Consumer Responses in the Lodging Industry: Functions of Green Marketing Motive and Appeal Type.” Doctoral Dissertations. http://trace.tennessee.edu/utk_graddiss/3487.

Yurchenko, Sergei N et al. "Towards Personal Copyefficient Refinement of Molecular Potential Energy Surfaces : Ammonia as a Case Study." 